\title{
Pengaruh Aktivitas Menghafal Al-Qur'an Terhadap Kecerdasaan Spiritual Peserta Didik Kelas X di MA Al-Huda Jatiluhur
}

\author{
Sari Hodijah \\ STAI DR KHEZ Muttaqien Purwakarta \\ Sarihodijah9@gmail.com \\ Dede Supendi \\ STAI DR KHEZ Muttaqien Purwakarta \\ dede.supendi82@gmail.com
}

DOI: https://doi.org/1052593/pdg.02.2.02

Naskah diterima: 01 Juli 2021, direvisi: 28 Juli 2021, disetujui: 28 Juli 2021

\begin{abstract}
Based on preliminary research conducted at MA Al-Huda regarding the activity of memorizing the Qur'an, temporary information was obtained, namely the existence of a tahfidz Al-Qur'an program carried out by students at MA Al-Huda as an effort to encourage the improvement of the spiritual intelligence of participants. educate. The purpose of this study is to find out how high the spiritual intelligence of students is driven by the activity of memorizing the Qur'an, so it can be said that there is an influence between the activity of memorizing the Qur'an on the spiritual intelligence of students. This research departs from the urgency of education that prioritizes educators who have good morals. The hypothesis in this study is that the more frequent the activity of memorizing the Qur'an, the higher the spiritual intelligence it has. A person who is trained to memorize the Qur'an will experience a very good increase in spiritual intelligence. Because by reciting the holy verses of the Qur'an, we have indirectly established a relationship with Allah, and made the Qur'an a means for dhikr to Allah. This study uses quantitative research methods with correlational methods. For the sampling technique using a saturated sample with a sample of 33 students. As for the technique of data collection is done by means of observation, interviews, and distributing questionnaires with Likert scale measurements. Analysis of the data used is quantitative data by testing the validity and reliability of all instruments and then testing the hypothesis to the level of correlation of the two variables studied. In this study, it was found that a moderate level of correlation between the activity of memorizing the Qur'an had an influence on the spiritual intelligence of students. By getting the results of the effect based on the calculation of the correlation coefficient of 0.254, it means that there is a moderate influence between the activity of memorizing the Qur'an on the spiritual intelligence of students.
\end{abstract}

Keywords: Al-Qur'an Memorizing Activity, Spiritual Intelligence 


\begin{abstract}
Abstrak
Berdasarkan penelitian pendahuluan yang dilakukan di MA Al-Huda mengenai aktivitas menghafal Al-Qur'an diperoleh informasi sementara yaitu adanya program tahfidz Al-Qur'an yang dilaksanakan oleh peserta didik di MA Al-Huda sebagai upaya untuk mendorong peningkatan kecerdasan spiritual yang dimiliki peserta didik. Tujuan penelitian ini tidak lain adalah untuk mengetahui seberapa tinggi kecerdasan spiritual yang dimiliki peserta didik yang didorong oleh aktivitas menghafal Al-Qur'an, sehingga dapat dikatakan adanya pengaruh antara aktivitas menghafal Al-Qur'an terhadap kecerdasaan spiritual peserta didik. Penelitian ini bertolak pada urgensi pendidikan yang mengutamakan pendidik yang berakhlakul karimah. Hipotesis pada penelitian ini adalah semakin sering aktivitas menghafal Al-Qur'an maka semakin tinggi kecerdasan spiritual yang dimilikinya. Seseorang yang dilatih untuk menghafal Al-Qur'an akan mengalami peningkatan kecerdasan spiritual dengan sangat baik. Karena dengan melantunkan ayat-ayat suci AlQur'an secara tidak langsung telah menjalin hubungan dengan Allah Swt, dan menjadikan Al-Qur'an sebagai sarana untuk berdzikir kepada Allah Swt. Penelitian ini menggunakan metode penelitian kuantitatif dengan metode korelasional. Untuk teknik pengambilan sampel menggunakan sampel jenuh dengan jumlah sampel 33 peserta didik. Adapun untuk teknik pengumpulan data dilakukan dengan cara observasi, wawancara, dan penyebaran angket dengan pengukuran skala likert. Analisis data yang digunakan adalah data kuantitatif dengan cara menguji validitas dan reliabilitas seluruh instrument kemudian diuji hipotesis sampai tingkat korelasi dari dua variable yang diteliti. Pada penelitian ini ditemukan tingkat korelasi yang sedang antara hubungan aktivitas menghafal Al-Qur'an memiliki pengaruh terhadap kecerdasan spiritual pesertadidik. Dengan didapatkan hasil pengaruh berdasarkan perhitungan koefisien korelasi sebesar 0,254, berarti terdapat pengaruh yang sedang antara aktivitas menghafal Al-Qu'an terhadap kecerdasan spiritual peserta didik.
\end{abstract}

Kata kunci : Aktivitas Menghafal Al-Qur'an, Kecerdasan Spiritual

\title{
A. Pendahuluan
}

Pada dasarnya pendidikan adalah laksana eksperimen yang tidak pernah selesai sampai kapanpun, sepanjang ada kehidupan manusia didunia ini. Dikatakan demikian, karena pendidikan murupakan bagian dari kebudayaan dan peradaban manusia yang terus berkembang. Hal ini sejalan dengan pembawaan manusia yang memiliki potensi kreatif, dan inovatif dalam segala bidang kehidupannya ${ }^{1}$

Potensi yang dimiliki manusia adalah potensi akal, jiwa, hati, dan panca Indra. Potensi yang diberikan oleh Allah untuk dimanfaatkan agar manusia dapat menjalani dan menikamati kehidupannya dengan baik. Dalam memanfaatkan apa yang telah

\footnotetext{
${ }^{1}$ Hasbullah. Dasar-dasar Ilmu Pendidikan,(Jakarta: Raja Grafindo Persada, 2009), IX.

78 | Paedagogie: P-ISSN: 2337-6848, E-ISSN : 2723-5971
} 
diberikan Allah, salah satunya melatih potensi akal untuk selalu digunakan berfikir. Diantara makhluk-makhluk Allah, hanya manusialah yang diberi akal oleh Allah. Diperintahkan agar menggunakan akal fikirannya untuk melaksanakan perintah dan larangan yang telah Allah berikan.

Untuk mempertajam penalaran/akal fikiran manusia, maka manusia tidak lepas dari berusaha untuk menuntut ilmu dalam bentuk apapun. Karenadengan menuntut ilmu, dapat memperluas wawasan pengetahuan. Seiring dengan perkembangan zaman, banyaknya pergaulan bebas, banyaknya pengaruh dari arah manapun, menuntut ilmu tanpa ada yang mendasari pasti terasa kurang menancap dalam hati. Sehingga perlu adanya dasar yang dapat dijadikan pegangan dalam kehidupan sehari-hari yang demikian juga Al-Qur'an sendiri menuntun agar umat muslim menerapkan pelaksanaan pendidikan yang integrative dan komprehensif. Pendidikan yang memadukan antara dimensi intelektual, emosional, dan semangat. ${ }^{2}$

Aktivitas menghafal Al-Qur'an adalah suatu proses kegiatan aktif menyimpan dan menjaga Al-Qurean dalam diri seseorang dengan sungguh-sungguh sebagai upaya untuk melestarikannya atau memelihara kalam Allah yaitu Al-Qur'an dengan cara mengulangulang bacaan Al-Qur'an baik membacanya maupun mendengarkannya.

Menurut para ahli, ada banyak kecerdasaan yang diberikan oleh Tuhan kepada manusia. Ada tiga macam kecerdasan yang sering dikenal yaitu kecerdasaan intelektual, kecerdasan emosional dan kecerdasan spiritual. Kecerdasan spiritual adalah kecerdasan yang mengangkat fungsi jiwa sebagai perangkat internal diri yang memiliki kemampuan dan kepekaan dalam melihat makna yang ada di balik sebuah kenyataan atau kejadian tertentu. Kecerdasan spiritual berkaitan dengan makna dan nilai pertama kali digagas dan ditemukan oleh Danah Zohar dan Ian Marshall. ${ }^{3}$

Undang-undang No. 20 tahun 2003 tentang sistem pendidikan nasional, menyatakan peserta didik adalah anggota masyarakat yang berusaha mengembangkan potensi diri melalui proses pembelajaran yang tersedia pada jalur, jenjang, dan jenis pendidikan tertentu.

Berdasarkan latarbelakang masalah yang telah diuraikan diatas, maka identifikasi masalah yang peneliti rumuskan antara lain:

\footnotetext{
${ }^{2}$ Mamang Muhamad Haerudin. Berkah Islam Indonesia, Jalan Dakwah Rohmatan Lil'alamin, (Jakarta: PT Elex Media Komputindo, 2015), 171.

${ }^{3}$ Akhmad Muhaimin Azzet. Mengembangkan kecerdasaan spiritual bagi anak, (Depok: Katahati), 31.
} 
1. Rendahnya minat menghafal Al-Qur'an di MA Al-Huda.

2. Rendahnya akhlak peserta didik di MA Al-Huda.

3. Adanya aktivitas menghafal Al-Qur'an yang dilihat dari perkembangannya mempengaruhi perilaku peserta didik.

4. Rendahnya minat peserta didik dalam mengikuti program Tahfidz Al-Qur'an.

5. Rendahnya kesadaran dalam mengelola kecerdasan spiritual yang dimiliki oleh peserta didik.

Permasalahan pada penelitian ini diperlukan batasan masalah supaya penelitian lebih terarah dari pembahasan yang diharapkan. Maka batasan masalah dalam penelitian ini yaitu:

Permasalahan pada penelitian ini diperlukan batasan masalah supaya penelitian lebih terarah dari pembahasan yang diharapkan. Maka batasan masalah dalam penelitian ini yaitu pengaruh aktivitas menghafal Al-Qur'an terhadap kecerdasan spiritual peserta didik kelas Xdi MA Al-Huda Jatiluhur

Berdasarkan rumusan masalah yang ada maka tujuan penelitian adalah:

1. Untuk mengetahui gambaran aktivitas menghafal Al-Qur'an di MA Al-Huda Jatiluhur.

2. Untuk mengetahui gambaran kecerdasan spiritual peserta didik kelas X di MA AlHuda Jatiluhur.

3. Untuk mengetahui seberapa besar pengaruh aktivitas menghafal Al-Qur'an terhadap kecerdasan spiritual peserta didik kelas X di MA Al-Huda Jatiluhur.

Hasil penelitian ini diharapkan dapat menambah ilmu pengetahuan dan dapat dijadikan sebagai gambaran mengenai pengaruh aktivitas menghafal Al-Qur'an terhadap kecerdasan spiritual peserta didik. Diharapkan mampu menambah khasanah keilmuan penulis guna memberikan manfaat kepada pihak-pihak yang membutuhkan. Dapat membantu memberikan informasi dan evaluasi bagi semua orang mengenai pengaruh aktivitas menghafal Al-Qur'an terhadap kecerdasan spiritual peserta didik. 


\section{B. Teori/Konsep}

\section{Aktivitas Menghafal Al-Qur'an}

Aktivitas adalah keaktifan, kegiatan. ${ }^{4}$ Menurut Zakiah Darajat, aktivitas adalah melakukan sesuatu dibawa ke arah perkembangan jasmani dan rohaninya. ${ }^{56}$ Sedangkan menghafal artinya berusaha meresapkan ke pikiran agar selalu ingat. ${ }^{7}$ Menurut Syaiful Bahri Djamarah, menghafal adalah kemampuan jiwa untuk memasukkan (learning), menyimpan (retention), dan menimbulkan kembali (remembering) hal-hal yang telah lampau. ${ }^{8}$ Menurut mahmud, menghafal adalah kumpulan reaksi elektrokimia rumit yang diaktifkan melalui beragam saluran indrawi, dan disimpan dalam jaringan syaraf yang sangat rumi dan unik diseluruh bagian otak. ${ }^{9}$

Dalam proses penghafalan, memori memiliki peranan yang sangat penting. Ingatan (memory) merupakan suatu daya yang dapat menerima, menyimpan dan memproduksi kembali kesan-kesan / tanggapan / pengertian. Dalam bukunya Nyayu Khodijah Walgito menyatakan bahwa memori adalah kemampuan jiwa untuk memasukkan (learning), menyimpan (retention) dan menimbulkan kembali (remembering) hal-hal yang telah lampau. Bruno dalam bukunya Nyayu Khodijah menyatakan bahwa, memori adalah proses mental yang meliputi pengkodean, penyimpanan, dan pemanggilan kembali informasi dan pengetahuan yang semuanya terpusat dalam otak.

Menghafal Al-Qur'an adalah suatu proses mengulang-ngulang bacaan Al-Qur'an baik dengan cara membaca maupun dengan cara mendengar, sehingga bacaan tersebut dapat melekat pada ingatan dan dapat diucapkan atau diulang kembali tanpa melihat mushaf Al-Qur'an. ${ }^{10}$

Dari pemaparan di atas, dapat di simpulkan bahwa aktivitas menghafal Al-Qur'an adalah suatu proses kegiatan aktif menyimpan dan menjaga Al-Qur'an dalam diri seseorang dengan sungguh-sungguh sebagai upaya untuk melestarikannya atau

\footnotetext{
${ }^{4}$ KBBI Offline

${ }^{5}$ Zakiah Darajat. Metodik Khusus Pengajaran Agama Islam, (Jakarta: Bumi Aksara, 2011), 138.

${ }^{6}$ Dina Fitriyani. Pengaruh Aktivitas Menghafal Alqur'an terhadap Kecerdasan Spiritual Santri Di Pondok Pesantren Anak-Anak Tahfidzul Qur'an (PPATQ) Raudlatul Falah Bermi Gembong Pati Tahun 2016, Disertasi (Semarang: UIN Walisongo,2016), 11.

7 Tim Penyusun Kamus Pusat Bahasa. Kamus Besar Bahasa Indonesia, 381.

${ }^{8}$ Syaiful Bahri Djamarah. Psikologi Belajar, (Jakarta: Rineka Cipta, 2008), 44.

${ }^{9}$ Mahmud. Psikologi Pendidikan. (Bandung: Pustaka Setia, 2010), 128.

${ }^{10}$ Dina Fitriyani. Pengaruh Aktivitas Menghafal ..., 17.
} 
memelihara kalam Allah yaitu Al-Qur'an dengan cara mengulang-ulang bacaan AlQur'an baik membacanya maupun mendengarkannya.

\section{Hukum Menghafal Al-Qur'an}

Semua ulama sepakat bahwa hukum menghafal Al-Qur'an adalah fardhu kifayah. Jika dalam suatu masyarakat sudah ada yang menghafal Al-Qur'an, maka bebaslah beban dalam masyarakat tersebut. Akan tetapi, jika tidak ada seorangpun yang menghafal Al-Qur'an, maka semua masyarakat tersebut berdosa. Hal ini bertujuan untuk menjaga Al-Qur'an dari pemalsuan, perubahan, dan pergantian sepeti yang pernah terjadi kepada kitab-kitab sebelumnya. ${ }^{11}$

\section{Metode Menghafal Al-Qur'an}

Adapun metode menghafal Al-Qur'an yaitu: ${ }^{12}$ Memahami makna ayat sebelum dihafal, mengulang-ulang membaca (bin-nadzar) sebelum menghafal, mendengarkan bacaan orang yang lebih ahli, sering menulis ayat-ayat Al-Qur'an, memerhatikan ayat atau kalimat yang serupa, selalu mengulang (takrir), tasmi'(memperdengarkan hafalan kepada orang lain).

\section{Manfaat Menghafal Al-Qur'an}

Adapun manfaat dari menghafal Al-Qur'an adalah sebagai berikut: ${ }^{13}$

1. Perbuatan yang paling agung secara mutlak. Karena dengan hafalnya Al-Qur'an maka akan membukakan seluruh pintu-pintu kebaikan.

2. ketika seseorang hafal Al-Qur'an berarti ia hafal sebagian besar ensiklopedi secara mutlak.

3. Seseorang yang hafal Al-Qur'an, ia akan memiliki gaya bahasa yang kuat sebab kefasihan (balaghah) ayat-ayat Al-Qur'an. Serta memiliki lebih banyak kemampuan dalam berinteraksi dengan orang lain, menahan beban dan kesabaran.

4. Al-Qur'an adalah obat untuk penyakit-penyakit jasmani dan jiwa.

\footnotetext{
${ }^{11}$ Ridhoul Wahidi \& M. Syukron. Beli Surga Dengan Al-Qur'an, (Media Presindo, 2013), 41.

12 Erliz zaenatur. Pengaruh Program Tahfidz Terhadap Kecerdasan Emosional Dan Spiritual Peserta Didik SDN Kampung Dalem 1 Tulungagung, Disertasi (Tulungagung: IAIN Tulungagung), 23.

${ }^{13}$ Abdud Da-im al-Kahiil. Metode Baru Meghafal Alquran, (Jawa Tengah: PP), 8. 


\section{Hambatan-hambatan dalam Menghafal Al-Qur'an}

Berikut adalah hal-hal yang dapat menghambat dalam menghafal al-Qurean, yaitu: ${ }^{14}$ Tidak menguasai makhorijul huruf dan tajwid, Tidak sabar, Tidak sungguh-sungguh, Berganti-ganti mushaf Al-Qurean.

\section{Kaidah-kaidah dalam Menghafal Al-Qur'an}

Ada dua jenis kaidah dalam menghafal Al-Qur'an yaitu kaidah pokok dan kaidah pendukung dalam menghafal Al-Qur'an. ${ }^{15}$

1. Kaidah-kaidah pokok merupakan kaidah-kaidah yang tidak ada pilihan untuk penghafal Al-Qur'an kecuali untuk dilaksanakan secara mutlak. Kaidah-kaidah pokok dalam menghafal Al-Qur'an Yaitu: ${ }^{16}$ Ikhlas, Tekad yang Kuat, Paham akan Keutamaan Menghafal Al-Qur'an, Mengamalkan Ayat-ayat Al-Qur'an yang dihafalnya, Meninggalkan Kemaksiatan, Berdo'a kepada Allah, Pemahaman yang Benar terhadap Kandungan Ayat yang Dihafalnya, Memerhatikan Kaidah-kaidah Tajwid, Membaca Al-Qur'an secara Rutin, Menggunakan Ayat-ayat Al-Qur'an yang telah Dihafal dalam Shalat.

2. Kaidah-kaidah pendukung merupakan kaidah yang dapat menerima akan perubahan, tambahan dan penghapusan sampai batas-batas tertentu. Kaidah-kaidah pendukung dalam Menghafal Al-Qur'an yaitu: ${ }^{17}$ Buatlah Perencanaan yang Jelas, Bekerjasamalah dengan orang lain, Bawalah Selalu Mushaf Kecil di dalam Saku Pakaian, Simaklah dengan Baik Bacaan Imam Ketika Shalat Berjamaah, Dahulukan Menghafal Surat-surat yang Paling Mudah, Tetaplah pada Satu Jenis Mushaf, Janganlah Berpindah ke Surat yang Baru Sebelum yang Lama Hafal dengan Lancar, Jadikan Setiap Satu Surat sebagai Satu Kesatuan yang Utuh, Perhatikan secara Seksama Ayat-ayat Mutasyabihat, Ikutilah Perlombaan-perlombaan Hifzhul Qur'an.

\footnotetext{
${ }^{14}$ Dina Fitriyani. Pengaruh Aktivitas Menghafal ..., 27.

15 Raghib as-Sirjani. Panduan Cepat \& Mudah Menghafal Al-Qur'an, Mukjizat Menghafal Al-qur'an. (Jakarta: PT Bestari Buana Murni), 45.

${ }^{16}$ Ibid.

${ }^{17} \mathrm{Ibid}$.
} 


\section{Indikator Menghafal Al-Qur'an}

Indikator dari aktifitas menghafal Al-Qur'an yaitu: ${ }^{18}$ Membaca sebelum menghafal Al-Qur'an, Menyimakkan hafalan Al-Qur'an, Mendengarkan hafalan Al-Qur'an, Mengulang-ulang hafalan yang telah diperoleh

\section{Kecerdasan Spiritual Peserta Didik}

Menurut Zohar dan Marshall yang dimaksud kecerdasan spiritual adalah kecerdasaan untuk menghadapi dan memecahkan persoalan makna dan nilai, yaitu kecerdasaan untuk menmpatkan perilaku dan hidup kita dalam konteks makna yang lebih luas dan kaya, kecerdasaan untuk menilai tindakan ataujalan hidup seseorang lebih bermakna dibandingkan dengan yang lain. ${ }^{19}$ Undang-undang No. 20 tahun 2003 tentang sistem pendidikan nasional, menyatakan peserta didik adalah anggota masyarakat yang berusaha mengembangkan potensi diri melalui proses pembelajaran yang tersedia pada jalur, jenjang, dan jenis pendidikan tertentu.

Dari pemaparan diatas dapat disimpulkan bahwa kecerdasaan spiritual peserta didik adalah suatu kemampuan yang dimiliki seorang peserta didik untuk menghadapi dan memecahkan makna, masalah, kontrol diri, dan menggunakan hati nuraninya dalam kehidupan. Dengan kecerdasaan spiritual peserta didik akan lebih mampu untuk menyelesaikan permasalahan hidup.

\section{Indikator Kecerdasan Spiritual Peserta didik}

Menurut Zohar dan Marshall, ada sembilan tanda orang yang memiliki kecerdasan spiritual, yakni sebagai berikut: ${ }^{20}$ Kemampuan bersikap fleksibel, Derajat kesadaran diri yang tinggi, Kecakapan untuk menghadapi penderitaan, Kecakapan untuk menghadapi rasa takut, Kualitas hidup yang diilhami oleh visi dan nilai, Enggan melakukan hal yang merugikan, Kecenderungan melihat keterkaitan berbagai hal, Ditandai oleh kecenderungan untuk bertanya "mengapa" atau"bagaimana jika"Pertanyaan "mengapa" atau "bagaimana jika" biasanyadilakukan oleh seseorang untuk mencari jawaban yang mendasar, Pemimpin yang penuh pengabdian dan bertanggung jawab.

\footnotetext{
${ }^{18}$ Erliz zaenatur. Pengaruh Program ..., 24.

${ }^{19}$ Desmita. Psikologi Perkembangan. (Bandung PT Remaja Rosdakarya,2005), 174.

${ }^{20}$ Erliz zaenatur. Pengaruh Program Tahfidz ...,34. 


\section{Faktor-faktor yang Mempengaruhi Kecerdasaan Spiritual}

Dalam perkembangannya, kecerdasan spiritual dipengaruhioleh beberapa faktor yang dapat mempengaruhi antara lain: ${ }^{21}$ Keberhasilan seseorang dalam mengembangkan beberapa bagiandari dirinya sendiri, Pendidikan yang diberikan oleh keluarga sejak kecil, Lingkungan sekitar yang dapat memberikan pengaruh terhadapkeadaan spiritual seseorang.

\section{Manfaat Kecerdasaan Spritiual Peserta didik}

Beberapa manfat yang didapatkan dengan menerapkan Spiritual Quotient sebagai berikut $^{22}$ :

1. Spiritual Quotient telah menyalakan manusia untuk menjadi manusia seperti adanya sekarang dan memberi potensi untuk tumbuh dan berubah, serta menjalani lebih lanjut evolusi potensi manusiawi.

2. Untuk menjadi kreatif, luwes, berwawasan luas, atau spontan secara kreatif.

3. Untuk berhadapan dengan masalah eksistensi, yaitu saat merasa terpuruk, terjebak oleh kebiasaan, kekhawatiran, dan masalah masalalu akibat penyakit dan kesedihan. SQ menjadikan sadar bahwa memiliki masalah setidaknya bisa berdamai dengan masalah tersebut.

4. Pedoman saat berada pada masalah yang paling menantang.

5. Untuk menjadi lebih cerdas secara spitua dalam beragama.

6. Untuk menyatukan hal-hal yang bersifat intrapersonal dan interpesonal, sertamenjembatani kesenjangan antara diri sendidi dan orang lain.

7. Untuk mencapai perkembangan diri yang lebih utuh karena setiap orang memiliki potensi untuk itu.

8. Untk berhadapan dengan masalah baik dan jahat, hidup dan mai, dan asal-usul sejati dari pendeitaan dan keputusan manusia.

Untuk dapat memahami bahwa setiap saat, detik, dan desah napas selalu diperhatikan Allah dan tidak pernah luput dari pengawasan Alah.

\footnotetext{
${ }^{21}$ Akhmad Muhaimin Azzet. Mengembangkan kecerdasaan spiritual bagi anak, (Depok: Katahati), 32.

22 Abd.Wahab \& Umiarso. Kepemimpinan Pendidikan dan Kecerdasan Spiritual, (Depok: Ar-Ruzz Media), 57.
} 


\section{Metodologi}

Pendekatan dalam penelitian ini menggunakan pendekatan kuantitatif. Penelitian kuantitatif merupakan pendekatan yang di dalam usulan penelitian, proses, hipotesis, turun ke lapangan, analisis data dan kesimpulan data sampai dengan penulisannya mempergunakan aspek pengukuran, perhitungan, rumus dan kepastian data numeric. Pendekatan tersebut dipilih dengana alasan karena kuantitatif bekerja menggunakan sample untuk memecahkan persoalan yang di hadapi dan juga metode kuantitatif memberikan penjelasan yang lebih tepat terhadap fakta yang di hadapi. Penelitian ini menggunakan metode korelasional. Metode korelasional adalah hubungan antara dua variable atau lebih sebagaimana adanya tanpa perlakuan. Untuk mendapatkan data yang akan diolah, peneliti menggunakan data kuisioner. Metode kuisioner merupakan teknik pengumpulan data yang dilakukan dengan cara memberi seperangkat pertanyaan atau pernyataan tertulis kepada responden untuk dijawabnya. Metode tersebut dipilih untuk mengetahui hubungan dan tingkat hubungan antara dua variabel atau lebih tanpa ada upaya untuk mempengaruhi variabel tersebut.

Penelitian ini bertempat di MA Al-Huda yang beralamatkan di JL. Ir. H Juanda, Cilegong Jatiluhur, Purwakarta, Jawa Barat. Dan subjek penelitian nya yaitu terfokus pada siwa siswi kelas X di MA AL-Huda. Pemilihan tempat tersebut berdasarkan pada jarak tempuh penulis terhadap sekolah, dan juga situasi kondisi lingkungan sekolah.

Penelitian ini di mulai pada bulan September sampai dengan November 2019 pada saat kegiatan PPLG. Kemudian di lanjutkan pada bulan Maret sampai dengan Juli 2020. Penelitian ini terbagi pada empat tahap, yaitu: Tahap Persiapan, Tahap Pelaksanaan, Tahap Pengolahan Data, Tahap Sidang Skripsi.

Populasi adalah keseluruhan objek penelitian ${ }^{23}$. Penelitian yang dilaksanakan di Ma Al-Huda Jatiluhur memiliki populasi sebanyak 33 peserta didik dari tingkatan kelas X. Dalam penelitian ini menggunakan teknik non probabilitas, yaitu teknik sampling jenuh. Sample jenuh adalah teknik berdasarkan populasi yang digunakan sebagai sample berhubungan dengan jumlah populasi yang sangat kecil, kadang-kadang kurang dari 30 orang atau dapat digunakan jika penelitian yang ingin dibuat memliki kesalahan yang relatif kecil, teknik ini disebut juga dengan sensus ${ }^{24}$

\footnotetext{
${ }^{23}$ Johar Arifin. SPSS 24 untuk penelitian dan skripsi. (Jakarta: PT Elex Media Komputindo), 7.

24 Ibid., 710 
Teknik pengumpulan data difokuskan pada data primer, adapun teknik pengumpulan data yang dilakukan pada penelitian ini yaitu dengan cara wawancara, menggunakan kuesioner dan observasi.

Teknik pengumpulan data ini mengacu kepada sumber data variable $\mathrm{x}$ dan y yaitu pengaruh aktivitas menghafal Al-Qur'an terhadap kecerdasaan spiritual peserta didik di MA Al-Huda. Peneliti menggunakan angket dengan menggunakan pengukuran skala likert.

Pada instrumen penelitian yang menggunakan Skala Likert memiliki tingkatan dari segi negatif hingga positif. Penelitian ini menggunakan angket yang berupa pernyataan. Responden diminta untuk memiliki kategori jawaban yang sesuaai dengan keadaannya dan menceklis pada kolom kategori yang ada. Kategori-kategori tersebut yaitu selalu, sering, kadang-kadang, pernah dan tidak pernah.

Data yang akan diolah dalam penelitian seringkali diperoleh dari responden degan cara menyebarkan kuesioner. Jawaban yang diperoleh dari responden selanjutnya diringkas dalam tabel sebelum dilah degan program aplikasi SPSS. Pengolahan dengan SPSS dilakukan untuk menguji validitas dan reliabilitas jawaban responden. Kuesioner dinyatakan valid jika pertanyaan yang dibuat mampu mengungkap sesuatu yang akan diukur oleh kuesioner tersebut dan terdapat tiga jenis validitas.

Instrumen pengumpulan data (khususnya kuesioner) yang baik, paling tidak memenuhi lima kriteria, yaitu: validitas, reliabilitas, sensitivitas, obyektivitas, fisibilitas.

\section{Hasil dan Pembahasan}

Analisis data memberikan gambaran umum tentang data yang terkumpul sesuai dengan variabel yang diteliti. Maka analisis data yang terkumpul tersebut dikelompokan menjadi dua bagian yaitu : aktivitas menghafal Al-Qur'an (X), dan kecerdasan spiritual pesertadidik (Y). Data tersebut merupakan hasil kuantufikasi terhadap jawaban responden dari angket yang telah disebarkan.

Proses kuantufikasi dilakukan dengan cara pemberian skor pada masing-masing butir pernyataan dalam angket yang telah diisi oleh responden. Setelah diolah dari data mentah dengan menggunakan alat hitung computer yaitu SPSS. 22, Menggambarkan Uji Instrumen (Validitas dan Reabilitas) sudah valid dan reliable, prosentase, Ukuran Pemusatan Data (Mean, Median Modus), Ukuran penyebaran Data (Range, Varians, 
Standar Deviasi), Display data dalam bentuk Histogram, Uji Prasyarat Analisis tiap Variabel (Uji Normalitas dan Linearitas), dan Uji Hipotesis.

Pada uji instrument sudah valid dan reliable dengan jumlah item variabel $X=14$ item dan jumlah item variabel $\mathrm{Y}=15$ item. Pada perhitungan prosentase, menghasilkan data yang menunjukan bahwa jawaban rata-rata responden masuk dalam kriteria "pernah" untuk pertanyaan variabel $\mathrm{X}$ dan jawaban rata-rata responden masuk dalam kriteria "pernah" untuk pertanyaan variabel $\mathrm{Y}$.

Pada ukuran pemusatan data, diperoleh hasil untuk variabel $\mathrm{X}$ yaitu : mean $=$ 53,45 , median $=52.00$, dan modus $=51,00$ sedangkan hasil untuk variabel $\mathrm{Y}$ yaitu $:$ mean $=62,55$, median $=62.00$ dan modus $=61$. Pada Ukuran penyebaran data, diperoleh hasil untuk variabel X yaitu : standar deviasi $=6,403$, varians $=41.00$, dan range $=25,00$, sedangkan hasil untuk variabel $\mathrm{Y}$ yaitu $:$ standar deviasi $=5,810$, varians $=33,756$, dan range $=23$.

Tabel 1. Ukuran Pemusatan Data

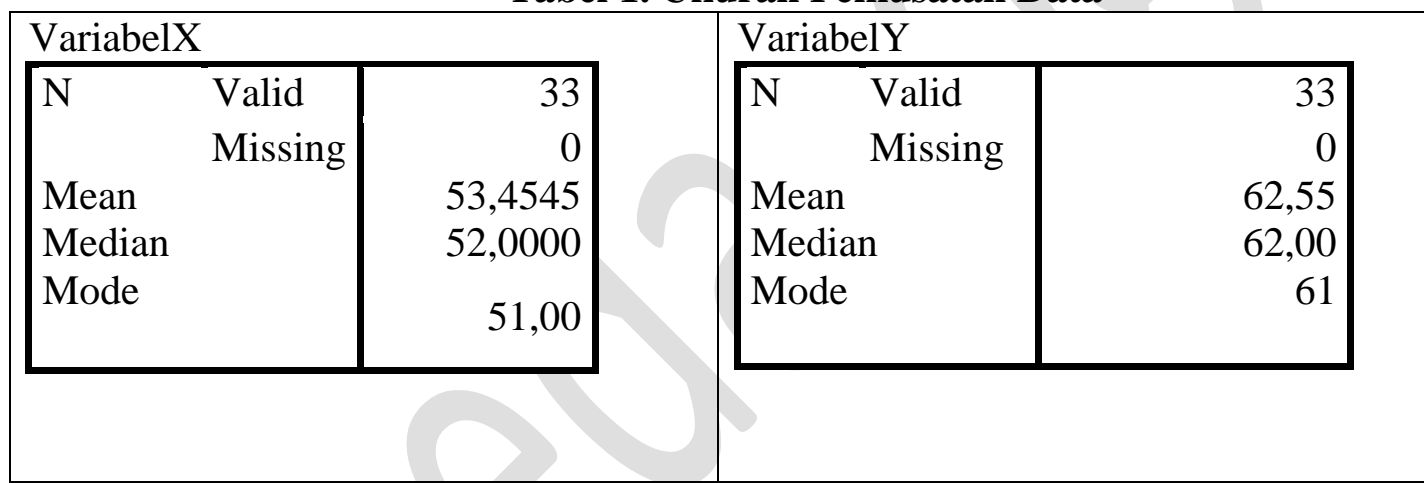

Tabel 2. Ukuran Penyebaran Data

\begin{tabular}{|c|c|c|c|c|c|}
\hline \multicolumn{3}{|c|}{ VariabelX } & \multicolumn{3}{|c|}{ Variabel Y } \\
\hline \multirow[t]{2}{*}{$\mathrm{N}$} & Valid & 33 & $\mathrm{~N}$ & Valid & 33 \\
\hline & Missing & 0 & & Missing & 0 \\
\hline \multicolumn{2}{|c|}{ Std. Error of Mean } & 1,11472 & Std & of Mean & 1,011 \\
\hline \multicolumn{2}{|c|}{ Std. Deviation } & 6,40357 & Std & ation & 5,810 \\
\hline \multicolumn{2}{|c|}{ Variance } & 41,006 & $\mathrm{Va}$ & & 33,756 \\
\hline \multicolumn{2}{|c|}{ Range } & 25,00 & Ra1 & & 23 \\
\hline \multicolumn{2}{|c|}{ Minimum } & 41,00 & $\mathrm{Mi}$ & & 50 \\
\hline \multicolumn{2}{|c|}{ Maximum } & 66,00 & Ma & & 73 \\
\hline
\end{tabular}

Pada uji normalitas, diketahui bahwa nilai signifikasi variabel $\mathrm{X}$ (aktivitas menghafal Al-Qur'an) sebesar 0,18 dan nilai signifikansi variabel Y (kecerdasan 
spiritual pesertadidik) sebesar 0.49 lebih besar dari 0.05 , sehingga dapat sisimpulkan bahwa data yang peneliti uji berdistribusi normal. Pada uji linearitas, diperoleh nilai signifikasi sebesar 0.792 lebih besar dari 0.05, yang artinya terdapat hubungan linear secara signifikan antara variabel $\mathrm{X}$ (aktivitas menghafal Al-Qur'an) dengan variabel $\mathrm{Y}$ (kecerdasaan spiritual peserta didik).

\section{Tabel 3. Uji Normalitas}

Tests of Normality

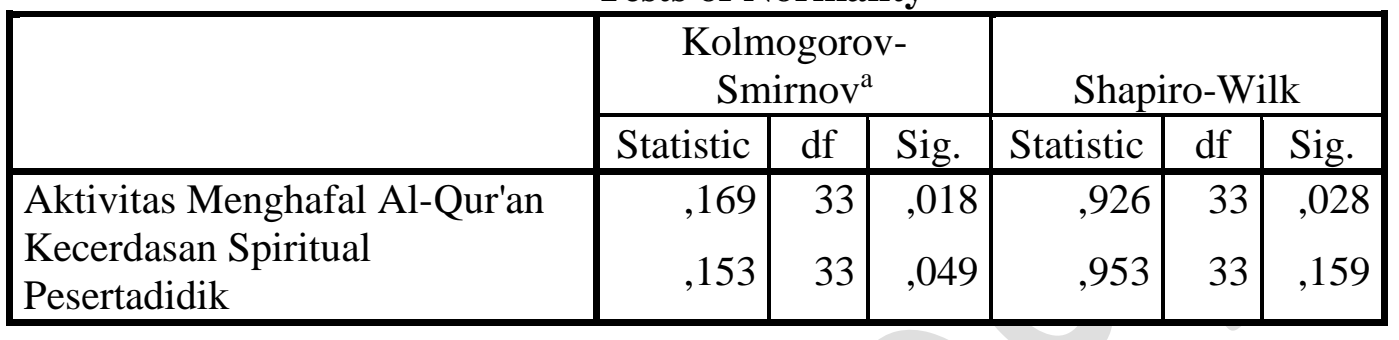

\section{Tabel 4. Uji Linearitas}

\begin{tabular}{|c|c|c|c|c|c|c|c|}
\hline & & & $\begin{array}{l}\text { Sum of } \\
\text { Squares }\end{array}$ & df & $\begin{array}{c}\text { Mean } \\
\text { Square }\end{array}$ & $\mathrm{F}$ & Sig. \\
\hline \multirow{6}{*}{$\begin{array}{l}\text { Kecerdasan } \\
\text { Spiritual } \\
\text { Pesertadidik } \\
\text { * Aktivitas } \\
\text { Menghafal } \\
\text { Al-Qur'an }\end{array}$} & Between & (Combined) & 357,148 & 13 & 27,473 & ,722 &, 723 \\
\hline & Groups & Linearity & 69,422 & 1 & 69,422 & 1,824 & , 193 \\
\hline & & Deviation & & & & & \\
\hline & & $\begin{array}{l}\text { from } \\
\text { Linearity }\end{array}$ & $28 \%, 727$ & 12 & 23,977 & ,630 & -792 \\
\hline & \multicolumn{2}{|c|}{ Within Groups } & 723,033 & 19 & 38,054 & & \\
\hline & \multicolumn{2}{|l|}{ Total } & 1080,182 & 32 & & & \\
\hline
\end{tabular}

Pada koefisien korelasi yang ditemukan sebesar 0,254 , berarti terdapat pengaruh yang rendah antara aktivitas menghafal Al-Qur'an terhadap kecerdasan spiritual pesertadidik. Pada uji signifikasi, diperoleh harga Fhitung sebesar 2.129, sedangkan $\mathrm{F}_{\text {tabel }}$ pada signifikasi $0.05 \mathrm{dan} \mathrm{dk}=33-2=31$ taraf kesalahan 5\% diperoleh $\mathrm{F}_{\text {tabel }}=4,16$ maka pada variabel $\mathrm{X}$ “aktivitas menghafal Al-Qur'an" terhadap variabel $\mathrm{Y}$ "kecerdasaan spiritual pesertadidik". Terdapat pengaruh yang signifikan. 
Tabel 5. Koefisien Korelasi

Correlations

\begin{tabular}{|ll|r|r|}
\hline & \multicolumn{1}{|c|}{$\begin{array}{c}\text { Aktivitas } \\
\text { Menghafal } \\
\text { Al-Qur'an }\end{array}$} & $\begin{array}{c}\text { Kecerdasan } \\
\text { Spiritual } \\
\text { Pesertadidik }\end{array}$ \\
\hline Aktivitas Menghafal Al-Qur'an & Pearson & 1 &, 254 \\
& Correlation & &, 155 \\
& Sig. (2-tailed) & 33 & 33 \\
& $\mathrm{~N}$ &, 254 & 1 \\
\hline Kecerdasan Spiritual & Pearson &, 155 & 33 \\
Pesertadidik & Correlation & 33 & \\
& Sig. (2-tailed) & $\mathrm{N}$ & \\
& $\mathrm{N}$ & & \\
& & & \\
\end{tabular}

Tabel 6. Uji Signifikasi

$\mathrm{ANOVA}^{\mathrm{a}}$

\begin{tabular}{|ll|r|r|r|r|c|}
\hline Model & & \multicolumn{1}{c|}{$\begin{array}{c}\text { Sum of } \\
\text { Squares }\end{array}$} & df & $\begin{array}{c}\text { Mean } \\
\text { Square }\end{array}$ & F & \multicolumn{1}{c|}{ Sig. } \\
\hline 1 & Regression & 69,422 & 1 & 69,422 & 2,129 &, $155^{\mathrm{b}}$ \\
& Residual & 1010,760 & 31 & 32,605 & & \\
& Total & 1080,182 & 32 & & & \\
\hline
\end{tabular}

a. Dependent Variable: Kecerdasan Spiritual Pesertadidik

b. Predictors: (Constant), Aktivitas Menghafal Al-Qur'an

Pada koefisien determinasi sebesar $0,254^{2}$ x $100=6,45 \%$ atau bisa dikatakan bahwa variabel $\mathrm{Y}$ dipengaruhi oleh variabel $\mathrm{X}$ sebesar $=6,45$. Pada persamaan regresi ( $\hat{\mathrm{Y}}=\mathrm{a}+\mathrm{b} \mathrm{X}), \hat{\mathrm{Y}}=50.250+0.230 \mathrm{X}$ signifikan dan linear.

\section{Tabel 7. Koefisien Determinasi}

Model Summary

\begin{tabular}{|c|c|c|c|c|c|}
\hline Model & $\mathrm{R}$ & $\mathrm{R}$ Square & $\begin{array}{c}\text { Adjusted R } \\
\text { Square }\end{array}$ & $\begin{array}{c}\text { Std. Error of } \\
\text { the Estimate }\end{array}$ & $\begin{array}{c}\text { Durbin- } \\
\text { Watson }\end{array}$ \\
\hline 1 &, $254^{\mathrm{a}}$ &, 064 &, 034 & 5,710 & 2,475 \\
\hline
\end{tabular}

a. Predictors: (Constant), Aktivitas Menghafal Al-Qur'an

b. Dependent Variable: Kecerdasaan Spiritual Peserta didik

Hasil penelitian yang dideskripsikan tersebut diatas dapat dipaparkan bahwa nilai hitung masing-masing bahan uji memiliki probalitas yang signifikan dengan menggunakan tarif nyata 0.05 . Dengan demikian dapat dikatakan bahwa hipotesis yang diajukan : “terdapat pengaruh antara aktivitas menghafal Al-Qur'an terhadap 
kecerdasan spiritual pesertadidik di kelas X MA Al-Huda Jatiluhur Tahun 2019/2020”, kebuka kebenarannya atau diterima.

Berdasarkan hasil penelitian, menunjukan angka presentase yang bisa dikatakan rendah menandakan bahwa aktivitas menghafal Al-Qur'an mempengaruhi kecerdasan spiritual pesertadidik di kelas X MA Al-Huda Jatiluhur Tahun 2019/2020.

\section{E. Simpulan}

Berdasarkan data-data yang diperoleh dalam penelitian yang berjudul "Pengaruh Aktivitas Menghafal Al-Qur'an Terhadap Kecerdasan Spiritual Pesertadidik di kelas X MA Al-Huda Jatiluhur" ini, maka dapat disimpulkan bahwa: Pertama, Realitas dari Aktivitas Menghafal Al-Qur'an di kelas X MA Al-Huda Jatiluhur dinilai "sering" dengan perolehan rata-rata yaitu sebesar $76.36 \%$, dapat dijelaskan bahwa peserta didik sering melaksanakan aktivitas menghafal Al-Qur'an. Nilai rata-rata ini diperoleh berdasarkan penilaian pada indikator-indikator dari "aktivitas menghafal Al-Qur'an" (variabel X). Kedua, Realita dari Kecerdasan Spiritual Pesertadidik di kelas X MA AlHuda Jatiluhur dinilai tinggi, peserta didik memiliki kecerdasan spiritual yang tinggi dengan diperoleh nilai rata-rata yaitu sebesar $84.84 \%$. Nilai rata-rata ini diperoleh berdasarkan perhitungan dari indikator-indikator "kecerdasaan spiritual" (variabel Y). Ketiga, Realitas hubungan aktivitas menghafal Al-Qur'an memiliki pengaruh terhadap kecerdasan spiritual pesertadidik. Dengan didapatkan hasil pengaruh berdasarkan perhitungan koefisien korelasi sebesar 0,254 , berarti terdapat pengaruh yang sedang antara aktivitas menghafal Al-Qu'an terhadap kecerdasan spiritual peserta didik. Dan berdasarkan penghitungan uji signifikasi, diperoleh harga Fhitung sebesar 2,129, 118 sedangkan Ftabel pada signifikasi 0.05 dan $\mathrm{dk}=33-2=31$ taraf kesalahan 5\% diperoleh Ftabel $=0,344$, maka pada variabel X “Aktivitas Menghafal Al-Qur'an” terhadap variabel Y "Kecerdasan Spiritual Pesertadidik". Terdapat pengaruh yang signifikan. Selain itu, diketahui pada persamaan regresi $(\hat{Y}=a+b X), \hat{Y}=50.250+$ $0.230 \mathrm{X}$ signifikan dan linear. Dan pada koefisien determinasi sebesar 0,2542 x $100=$ $6,45 \%$ atau bisa dikatakan bahwa variabel Y (Kecerdasan Spiritual Pesertadidik) dipengaruhi oleh variabel X (Aktivitas Menghafal Al-Qur'an) sebesar $=6,45 \%$ dan 93,55\% dipengaruhi oleh faktor lain yang belum diketahui oleh peneliti. Dengan demikian dapat dikatakan bahwa aktivitas menghafal Al-Qur'an mempunyai pengaruh 
positif dan signifikan terhadap kecerdasan spiritual peserta didik di kelas X MA AlHuda Jatiluhur.

Berdasarkan hasil penelitian tersebut, peneliti dapat memberikan saran sebagai berikut: Pertama, Bagi orang tua agar senantiasa mendorong dan mendukung penuh anaknya dalam berbagai hal, khususnya kemampuan anak dalam menghafal Al-Qur'an agar terciptanya kecerdasaan spiritual yang dimiliki meningkat. Kedua, Bagi pesertadidik diharapkan mampu meningkatkan kemampuan menghafal Al-Qur'an dengan cara bersungguh-sungguh dan lebih giat lagi dalam menghafal dengan cara rutin menghafal dan meminta bantuan tutor teman sebaya maupun guru dalam menghafal AlQur'an. Ketiga, Bagi lembaga sekolah hendaknya lebih mengarahkan dan memotivasi pesertadidik agar semakin semangat dalam menghafal Al-Qur'an. Selain itu, pihak sekolah juga diharapkan mampu menanamkan nilai Qur'ani pada peserta didik agar ke depanya kecerdasan spiritual peserta didik dapat meningkat.

\section{DAFTAR PUSTAKA}

Abdullah, Ma'ruf. 2015. Metodologi Penelitian Kuantitaif, Sleman, Yogyakarta: Aswaja Presindo

Arifin, Johar. SPSS 24 untuk penelitian dan skripsi, Jakarta: PT Elex Media Komputindo As-Sirjani, R. Panduan Cepat \& Mudah Menghafal Al-Qur'an, Mukjizat Menghafal Al-Qur'an. Jakarta: PT Bestari Buana Murni

Azzet, Muhaimin, A. Mengembangkan kecerdasaan spiritual bagi anak. Depok: Katahati Da-im, Abdud. Metode Baru Meghafal Alquran, Jawa Tengah: PP Darajat, Zakiah. 2011. Metodik Khusus Pengajaran Agama Islam. Jakarta: Bumi Aksara Desmita. 2005. Psikologi Perkembangan. Bandung: PT Remaja Rosdakarya Djamarah, Bahri, S. 2008. Psikologi Belajar, Jakarta: Rineka Cipta Dr.Rifma. 2016. Optimalisasi Pembinanaan Kompetensi Pedagogik Guru. Jakarta; Kencana Firdaus, Zakaria. 2017. Pengaruh Pendidikan Agama Islam dan Budaya Religius Sekolah Terhadap Kecerdasan Emosional dan Spiritual Siswa, Jurnal al-Hikmah vol. 5 no. 2

Fitriyani, Dina. 2016. Pengaruh Aktivitas Menghafal Alqur'an terhadap Kecerdasan Spiritual Santri Di Pondok Pesantren Anak-Anak Tahfidzul Qur'an (PPATQ) Raudlatul Falah Bermi Gembong Pati Tahun 2016. Skripsi Semarang: UIN Walisongo 
Gunawan, Ce. 2020. Mahir Menguasai SPSS Panduan Praktis Mengolah Data Penelitian New Edition. Sleman: CV Budi Utama

Hasbullah. 2009. Dasar-dasar Ilmu Pendidikan, Jakarta: Raja Grafindo Persada

Martono, Nanang. 2014. Metode Penelitian Kuantitatif Analisis Isi Dan Analisis Data Sekunder. Jakarta: PT Raja Grafindo Persada.

Muhamad, Mamang. 2015 Berkah Islam Indonesia, Jalan Dakwah Rohmatan Lil'alamin. Jakarta: PT Elex Media Komputindo

Ridwan dan Sunarto. 2014. Pengantar Statistika Untuk Penelitian Pendidikan, Sosial, Ekonomi, Komunikasi dan Bisnis, Bandung: Alfabeta

Sholeh, Abdurahman. 1991. Teori-teori Pendidikan Berdasarkan Al-Qur'an, Terj. H.M.Arifin. Jakarta: Rineka Cipta

Siregar. Statistika Deskriptif...,

Sudjono. Pengantar Statistik Pendidikan..,

Sugiyono. Metode Penelitian “Kuantitatif, Kualitatif, dan R\&D”. Bandung: Alfabeta Bandung.

Tim Penyusun Kamus Pusat Bahasa, Kamus Besar Bahasa Indonesia

Wahab, A\& Umiarso. Kepemimpinan Pendidikan dan Kecerdasan Spiritual. Depok: Ar-Ruzz Media

Wahidi, R \& Syukron, M. 2013. Beli Surga Dengan Al-Qur'an. Media Presindo

Widianingsih Pipit. Pengaruh Pendidikan Dalam keluarga terhadap kepribadian siswa (penelitian deskriptif di SMPN Cikao), Disertasi Purwakarta: STAI DR KHEZ Muttaqien,

Wiwi Alawiyah Wahid, Alawiyah, W. 2014. Cara Cepat Menghafal Al-Qur'an, Jogjakarta: DIVA Press

Wulandari, Fitri. 2018. Korelasi Kemampuan Daya Ingat Dan Kecerdasan Spiritual Dengan Kecakapan Afektif Siswa Pada Mata Pelajaran Akidah Akhlak Kelas V Di MIN 1 PONOROGO Tahun Pelajaran 2017/2018, Skripsi Ponorogo: IAIN Ponorogo

Zaenatur, Erliz. Pengaruh Program Tahfidz Terhadap Kecerdasan Emosional Dan Spiritual Peserta Didik SDN Kampung Dalem 1 Tulungagung, Skripsi Tulungagung: IAIN Tulungagung 